\title{
$\beta$-Carotene conversion products and their effects on adipose tissue
}

\author{
Franck Tourniaire - Erwan Gouranton · Johannes von Lintig • \\ Jaap Keijer · M. Luisa Bonet · Jaume Amengual · Georg Lietz · \\ Jean-François Landrier
}

Received: 22 May 2009/Accepted: 27 May 2009/Published online: 26 June 2009

(C) Springer-Verlag 2009

\begin{abstract}
Recent epidemiological data suggest that $\beta$-carotene may be protective against metabolic diseases in which adipose tissue plays a key role. Adipose tissue constitutes the major $\beta$-carotene storage tissue and its functions have been shown to be modulated in response to $\beta$-carotene breakdown products, especially retinal produced after cleavage by $\beta$-carotene $15,15^{\prime}$-monooxygenase
\end{abstract}

Georg Lietz and Jean-François Landrier equally contributed to this work.

F. Tourniaire · G. Lietz ( $₫)$

School of Agriculture, Food, and Rural Development,

Newcastle University, King's Road,

NE2 1PN Newcastle upon Tyne, UK

e-mail: georg.lietz@ncl.ac.uk

E. Gouranton · J.-F. Landrier

INRA, UMR1260 Nutriments Lipidiques et Prévention des

Maladies Métaboliques, Marseille 13385, France

E. Gouranton · J.-F. Landrier

INSERM, U476, 13385 Marseille, France

E. Gouranton · J.-F. Landrier

Univ Aix-Marseille 1, Univ Aix-Marseille 2, Faculté de

Médecine, IPHM-IFR 125, 13385 Marseille, France

J. von Lintig

Department of Pharmacology, Case Western Reserve University,

Cleveland, OH, USA

\section{J. Keijer}

Human and Animal Physiology, Wageningen University,

Wageningen, The Netherlands

M. Luisa Bonet · J. Amengual

Laboratory of Molecular Biology, Nutrition and Biotechnology, and CIBER Fisiopatología de la Obesidad y Nutrición,

Universitat de les Illes Balears, Palma de Mallorca, Spain
(BCMO1), and retinoic acid arising from oxidation of retinal. However, the possibility exists that $\beta$-carotene in its intact form can also affect adipocyte function. Development of a knock out model and identification of a loss-offunction mutation have pointed out BCMO1 as being probably the sole enzyme responsible for provitamin A conversion into retinal in mammals. The utilisation of $\mathrm{BCMO}^{-1-}$ mice should provide insights on $\beta$-carotene effect on its own in the future. In humans, intervention studies have highlighted the huge interindividual variation of $\beta$-carotene conversion efficiency, possibly due to genetic polymorphisms, which might impact on response to $\beta$-carotene. This brief review discusses the processes involved in $\beta$-carotene conversion and the effect of cleavage products on body fat and adipose tissue function.

Keywords $\beta$-Carotene - Vitamin A - Adipose tissue . Metabolic diseases $\cdot$ Genetic variants

\section{Carotenoids and provitamin A}

Carotenoids are $\mathrm{C}_{40}$ lipophilic pigments produced by photosynthetic organisms. About 600 different compounds have been identified so far, of which 50 can be found in the human diet. However, only about 10 are present in significant amounts in human plasma [54]. Carotenoids can be divided into two groups according to their chemical structure: the carotenes, which are hydrocarbons, and the xanthophylls, which contain also oxygen and are therefore more polar than the carotenes. The difference in polarity has consequences on their tissue distribution and also influences repartition and exchange between lipoproteins $[46,70]$. Carotenoids containing an unsubstituted $\beta$-ring and a $\mathrm{C}_{11}$ polyene chain are termed provitamin $\mathrm{A}$ as they 
can be cleaved by animals to release retinal, which can be subsequently converted to retinol (vitamin A, see below). $\beta$-Carotene constitutes the main provitamin A source with a daily consumption of around 1-3 mg [23, 24, 27, 64].

A high dietary consumption or a high plasma carotenoid status has generally been associated with a decreased risk of chronic disease (such as cardiovascular disease, some types of cancer and ocular diseases) in observational studies [2, 40]. Furthermore, several studies have found a lower $\beta$-carotene status in patients suffering from type II diabetes or metabolic syndrome than in matched controls $[10,19,20,55,56,65,82]$. Oxidative stress has been implicated in the triggering and/or the perpetuation of chronic and metabolic diseases, and the hypothesis was developed that increased intake of antioxidants (carotenoids, polyphenols, tocopherols) would prevent oxidative stress and disease occurrence. Until recently, beneficial health effects attributed to carotenoids were associated with their capability of acting as "direct" antioxidants (e.g. as free radical scavengers) in lipophilic environments such as biomembranes and lipoproteins [45]. However, current research is investigating the possibility that the beneficial health effects of phytochemicals could be caused by modulation of gene expression and induced endogenous defence mechanisms [13].

Interestingly, several intervention trials have failed in showing any preventive effects of carotenoids on disease incidence, and in some cases long-term supra-physiological dosing has even proven to be harmful in people at risk of disease [5, 21]. These data suggest the existence of a window of benefit for $\beta$-carotene and that an optimal carotenoid status should be achieved via appropriate food intake to avoid disease development. Furthermore, this window of benefit might vary between individuals, depending on their lifestyle and genetic background, both being susceptible of modulating response to carotenoids, as discussed below. Human adipose tissue represents the main $\beta$-carotene store of the body [37] and has a key role in metabolic pathologies [34]. Therefore, it could be conceivable that a putative $\beta$-carotene effect would also occur in or be mediated by the adipose tissue. However, the underlying effects of $\beta$-carotene on health are still unclear and could involve antioxidant properties but also modulation of gene expression and/or cell communication by $\beta$-carotene and/or its derivatives [13].

\section{Carotenoid oxygenases}

At the intestinal level, $\beta$-carotene absorption is depending on three steps: (1) absorption at the enterocyte brush border membrane level, partly via the cholesterol transporters SR-BI and CD36 [11, 71] but also by passive diffusion
[83]; (2) enzymatic conversion of a fraction of absorbed $\beta$-carotene in a centric or eccentric fashion by the $\beta$-carotene $15,15^{\prime}$-monooxygenase BCMO1 (releasing retinal) or by the $\beta$-carotene $9^{\prime}, 10^{\prime}$-dioxygenase, $\mathrm{BCDO} 2$ (releasing $\beta$-apo-10'-carotenal and $\beta$-ionone), respectively (Fig. 2 , for review see [73]. Because production of other $\beta$-apocarotenals $\left(8^{\prime}, 12^{\prime}\right.$ and $\left.14^{\prime}\right)$ has also been reported, the existence of an additional enzymatic eccentric pathway (similar to fatty acid $\beta$-oxidation) has been proposed $[26,76]$, although production of such compounds could also occur by non enzymatic oxidation [80, 81]. Furthermore, the extent of $\beta$-carotene cleavage in enterocytes is speciesdependent: humans (and other species such as ferrets) but not rodents, absorb significant amounts of intact $\beta$-carotene [75]. Retinal is subsequently metabolised into retinol by retinal dehydrogenases (RDHs), followed by esterification to fatty acids by lecithin:retinol acyl transferase (LRAT) and acyl-CoA:retinol acyltransferase (ARAT) [60]. Retinyl esters are then packed into chylomicrons together with non-converted $\beta$-carotene [7]. A minor fraction of retinal is also oxidised irreversibly to retinoic acids (RAs) via the retinal dehydrogenases (RALDHs). The fate of apocarotenals has not been described in detail but a part of them is probably oxidised to the corresponding apocarotenoic acid. And finally, (3) the secretion of chylomicron into the lymph. More hydrophilic compounds such as non-esterified retinol and RA are secreted directly into the bloodstream [25].

Intervention studies in healthy volunteers have led to the description of a "low responder" phenotype and a "low converter" phenotype. Low or poor responders are defined as individuals who show little variation in plasma $\beta$-carotene concentration after acute or chronic supplementation. Low converters have a low postprandial conversion efficiency after supplementation, reflected by the retinyl ester/ $\beta$-carotene ratio measured in the chylomicron fraction [7]. Approximately, $45 \%$ of the western population can be classified as low converter [30, 47]. It has been established that conversion efficiency is depending at least in part on the vitamin A status [57], which is explained by the existence of a negative feedback of RA on BCMO1 mRNA expression [3, 66]. Besides, many studies have highlighted the huge interindividual variability in conversion efficiency, with a coefficient of variation being as high as $221 \%$ [7, 12, 30, 47]. Furthermore, according to [77] who investigated the kinetics of a labelled $\beta$-carotene dose [77], low responders would also display a lower conversion efficiency compared to normal responders (Fig. 1). However, it should be noticed that this study was using a small number of subjects, and that retinol and $\beta$-carotene were measured in plasma and not in the chylomicron fraction, indicating that non-intestinal lipoprotein fractions were included in the analysis which also contain retinol derived 


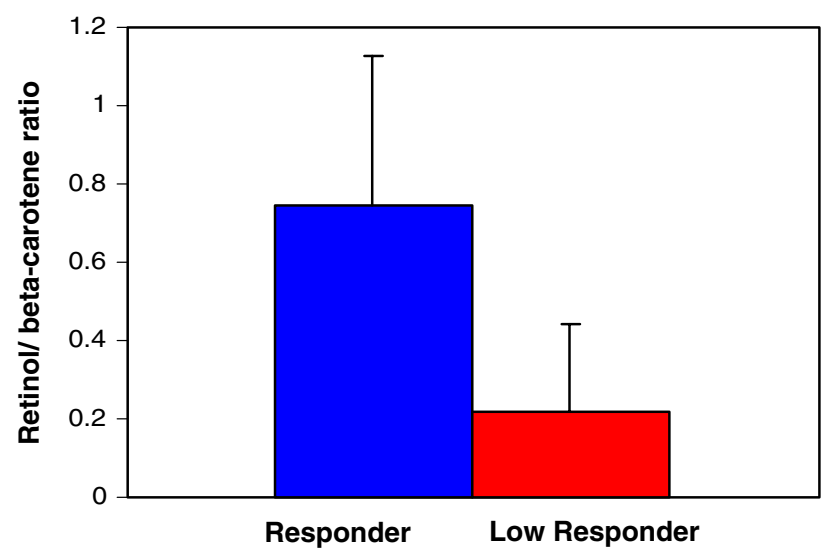

Fig. 1 Intestinal $\beta$-carotene conversion efficiency in normal and low responders in a Chinese population $(P<0.05)$. Data are taken from [77]

from $\beta$-carotene cleavage from tissues such as the liver. Finally, the body mass index was found to be inversely correlated with conversion efficiency [67], suggesting an interrelationship between $\beta$-carotene metabolism and adiposity in humans. In a recent study, [48] described the case of a patient displaying hypercarotenemia (plasma $\beta$-carotene was as high as $14.8 \mu \mathrm{M}$ ) combined with normal to low serum retinol level concentrations. The authors identified the existence of a heterozygote (dominant negative) genotype for the variant T170M of BCMO1 in this subject, whereas other candidate genes involved in retinol and $\beta$-carotene status $(B C D O 2, R B P 1$ and 2, RDH11, 12 and $14)$ only occurred in their wild-type alleles. Biochemical characterisation of the recombinant T170M BCMO1 protein in vitro showed that its activity was $\approx 90 \%$ lower than that of the wild type protein. These results suggest (1) the key role of BCMO1 in apparent $\beta$-carotene conversion efficiency in humans and (2) that a genetic variation exists in the $B C M O 1$ gene that can affect conversion efficiency. Even if the T170M mutation in BCMOl, given its rarity, cannot explain the common low converter trait, other polymorphisms in $B C M O 1$ could contribute. Indeed, our group studied the genetic variation in the human $B C M O 1$ gene to identify common polymorphisms in the regulatory and coding regions of the gene, and confirmed that two polymorphisms occurred in the Caucasian population at high frequencies, with allele frequency for the $\mathrm{A} 379 \mathrm{~V}$ and R267S variant $\mathrm{T}$ allele being 24 and $42 \%$, respectively [44]. Effect of identified mutations were evaluated in vitro, and confirmed in vivo through an intervention study with human volunteers and indicated that women carrying either the $B C M O 1379 \mathrm{~V}$ or $267 \mathrm{~S}+379 \mathrm{~S}$ variants have a decreased intestinal BC conversion efficiency [44]. Given the high frequency of these SNPs, they might account for a substantial part of the low converter trait. Additionally, polymorphisms in genes encoding proteins involved in any other step of $\beta$-carotene absorption/cleavage could influence the apparent conversion efficiency, and might explain, at least in part the very high inter-individual variation observed in supplementation studies. This hypothesis is supported by recent findings showing that single nucleotide polymorphisms (SNPs) present in certain genes coding for lipid transporters are correlated with plasma carotenoid status (Table 1). These results indicate that the carotenoid absorption/ metabolism can be influenced by genetic variation and could also help to identify new proteins involved in the carotenoid/ retinoid pathway.

\section{The $\beta$-carotene $15,15^{\prime}$-monooxygenase knock out model}

While non metabolised $\beta$-carotene is found in humans and ferrets, this is not the case in rodents, where most $\beta$-carotene is already cleaved in the intestine. It has been calculated that in rats, $95 \%$ of the $\beta$-carotene cleavage is achieved through the centric pathway (Fig. 2) and that eccentric cleavage products could be further metabolised to retinal via action of yet unidentified enzyme(s) [4]. As the physiological function of $\mathrm{BCDO} 2$ is still unknown, this

Table 1 SNPs related to $\beta$-carotene status/metabolism

\begin{tabular}{|c|c|c|c|c|}
\hline Gene & Location & rs number & Effect of the minor allele & Reference \\
\hline ApoB & C-516T (promoter) & rs934197 & Decreased fasting $\beta$-carotene in men & [9] \\
\hline BCMO1 & Exon $5 \mathrm{~T} 170 \mathrm{M}$ & $\mathrm{n} / \mathrm{a}$ & $\begin{array}{l}\text { High plasma } \beta \text {-carotene } \\
\text { Decreased catalytic activity in vitro }\end{array}$ & {$[48]$} \\
\hline BCMO1 & $\begin{array}{l}\text { Exon } 8(\mathrm{R} 267 \mathrm{~S}) \text { or } \\
\text { Exon } 6+\text { exon } 8(\mathrm{R} 267 \mathrm{~S}+\mathrm{A} 379 \mathrm{~V})\end{array}$ & $\begin{array}{l}\text { rs } 12934922 \\
\text { rs7501331 }\end{array}$ & $\begin{array}{l}\text { Decreased intestinal postprandial } \beta \text {-carotene } \\
\text { conversion efficiency, higher fasting } \beta \text {-carotene }\end{array}$ & [44] \\
\hline LIPC & C-480T (promoter) & rs 1800588 & $\begin{array}{l}\text { Higher } \beta \text {-carotene concentrations in homozygous } \\
\text { women }\end{array}$ & [8] \\
\hline LPL & Exon 8 S447X & rs328 & Lower fasting plasma $\beta$-carotene & {$[28]$} \\
\hline SR-BI & Intron 5 & $\mathrm{n} / \mathrm{a}$ & Decreased fasting $\beta$-carotene in men & [9] \\
\hline
\end{tabular}

$A p o B$ apolipoprotein B, BC $\beta$-carotene, $L I P C$ hepatic lipase, $L P L$ lipoprotein lipase, $S R-B I$ scavenger receptor type BI 


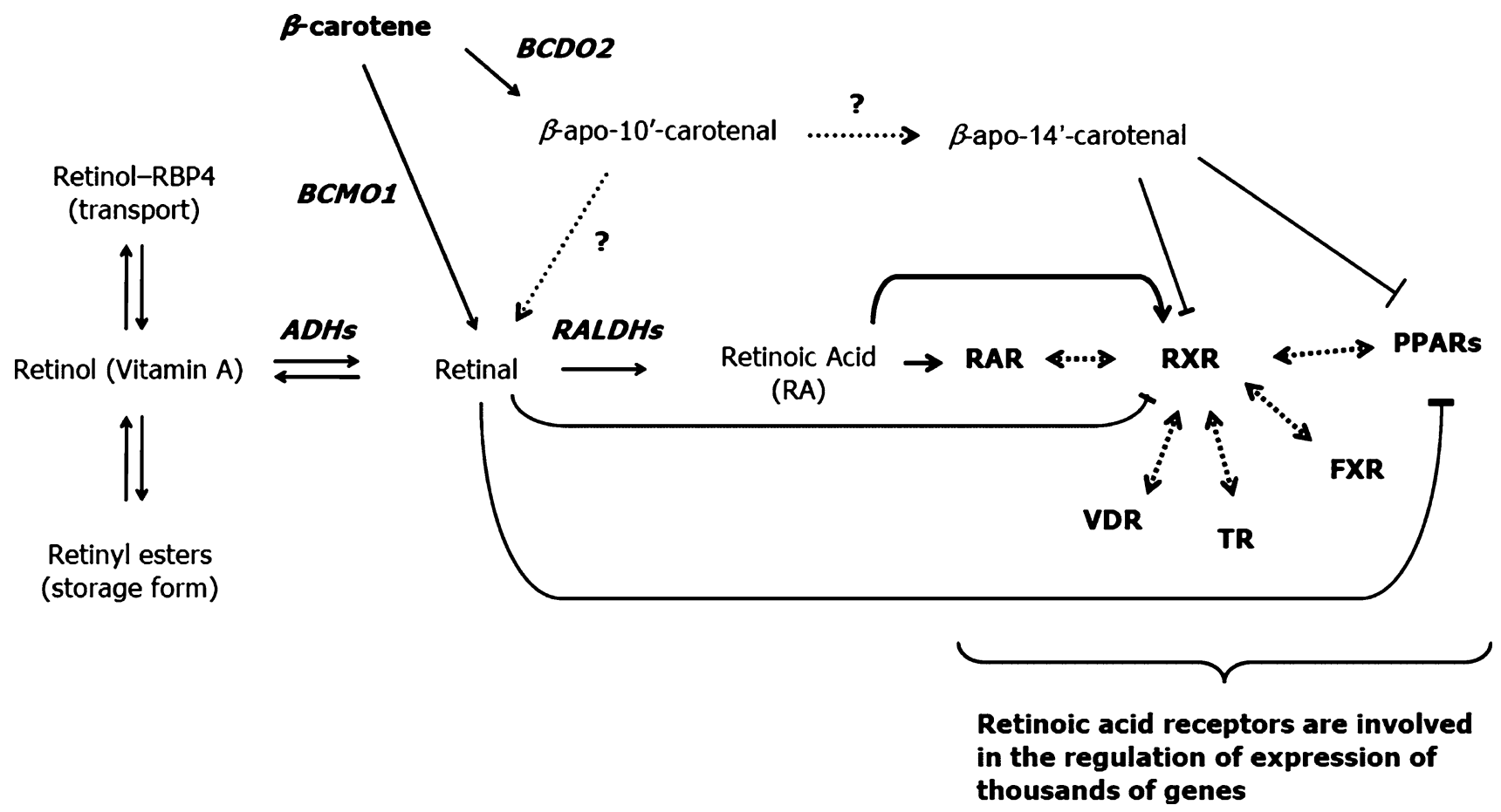

Fig. 2 Generic retinoid pathway (not taking into account of tissue specificities, see text for details). Retinol is stored in cells (mainly liver stellate cells) in the form of fatty acid esters. Its secretion in the bloodstream as retinol bind to the plasma retinol binding protein (RBP4) is tightly regulated so that the serum concentration in humans is constantly in the $2 \mu \mathrm{M}$ range. Retinol can be reversibly metabolised to retinal via RDHs. Retinal can also be oxidised to retinoic acid, the most active form of vitamin A via ligation to retinoid receptors RARs and RXRs. RXRs can interact as an heterodimer with many other nuclear receptors and regulate gene expression. $\beta$-carotene can be a

speculation would raise the possibility of $\mathrm{BCDO} 2$ acting as an alternative pathway for vitamin A formation from provitamin $\mathrm{A}$ in case of $\mathrm{BCMO} 1$ deficiency. To investigate this hypothesis, a mouse knock out model for $\mathrm{BCMOI}$ $\left(\mathrm{BCMO1}^{-/-}\right)$has been recently developed [29]. $\mathrm{BCMOI}^{-1-}$ mice fed with a $\beta$-carotene diet containing very-low amounts of vitamin $A$ accumulate $\beta$-carotene in their tissues and show 35 -fold higher plasma $\beta$-carotene concentrations compared to wild-type animals fed with the same diet. Furthermore, these animals were found unable to produce vitamin $\mathrm{A}$ from $\beta$-carotene as lower or even undetectable retinol and retinyl ester levels were found in the liver and other tissues known to express $B C M O 1$ (lung, testis, uterus). Interestingly, $B C D O 2$ mRNA expression was not elevated in the visceral adipose tissue of the knock out (KO) animals compared with the wild type (WT) controls, suggesting that enzymatic eccentric cleavage is not an alternative pathway for vitamin A formation from provitamin A, leaving the physiological function of $\mathrm{BCDO} 2$ unknown. These results suggest that BCMO1 is essential for maintaining vitamin A stores when $\beta$-carotene is the main source of vitamin A. Fierce et al. [18] argued source of retinal via centric cleavage by BCMO1. An alternative pathway has been proposed which would involve eccentric cleavage of $\beta$-carotene by $\mathrm{BCDO} 2$ (releasing $\beta$-apo- $10^{\prime}$-carotenal) as the initial step. $\beta$-apo-14'-carotenal, retinal, and retinoic acid have been shown to modulate nuclear receptor activity, sometimes in an opposite manner. BCDO2 $\beta$-carotene $9^{\prime}, 10^{\prime}$-dioxygenase, BCMO1 $\beta$-carotene $15,15^{\prime}$-monooxygenase, $F X R$ farnesoid $\mathrm{X}$ receptor, $R A R$ retinoic acid receptor, $R X R$ retinoid $\mathrm{X}$ receptor, $L X R$ liver $\mathrm{X}$ receptor, $T R$ thyroid hormone receptor, $P P A R$ peroxisome proliferator-activated receptor, ?: unidentified protein(s)

that BCMO1 is not essential for maintaining vitamin A stores due to their observation that liver vitamin A stores were not different between $B C M O 1^{-/-}$and WT animals. However, it is likely that this discrepancy is caused by high hepatic retinoid concentrations at the beginning of the study by [18] since (a) WT and $\mathrm{BCMOI}^{-1-}$ breeders were not subjected to a diet depleted of vitamin $\mathrm{A}$, and (b) the duration of the $\beta$-carotene/low vitamin $\mathrm{A}$ feeding period was shorter than in the study from [29]. Indeed, it has been shown that it is very difficult to trigger vitamin A deficiency in mice after weaning [53]. Thus, considering the current evidence, BCMO1 appears as being the sole enzyme involved in the conversion of $\beta$-carotene into retinal.

\section{Carotenoid/retinoid pathway and lipid metabolism}

Vitamin A status seems to play an important role in the development of liver steatosis in mice. A decrease in the expression of genes involved in fatty acid oxidation and an increase in hepatic macrocytic lipid accumulation and 
triglyceride concentration [36] have been observed in the liver of vitamin A deficient mice. Besides, the importance of RA was demonstrated in transgenic mice expressing retinoic acid receptor $\alpha$ dominant negative form (RARE) who develop microvesicular steatosis and spotty focal necrosis. Feeding these mice on a high retinoic acid diet reversed histological and biochemical abnormalities [63]. Surprisingly, $\mathrm{BCMOI}^{-1}$ mice were also found to develop liver steatosis [29]. However, it is important to note that in the case of $\mathrm{BCMOI}^{-1}$ mice, liver stores of WT and $\mathrm{KO}$ animals after feeding a vitamin A sufficient diet were comparable [29], suggesting that the development of steatosis in this animal model is directly related to BCMO1 function and not to vitamin A status. Therefore, it is possible that the local synthesis of vitamin A isomers from $\beta$-carotene could be mandatory for some physiological processes, such as described for zebrafish normal embryogenesis [43]. Other observations that support the existence of a relationship between carotenoid/retinoid and lipid metabolism come from studies investigating the effect of retinoids on body fat content. Bovine marbling (which is the presence of a high amount of fat in muscle) is enhanced in the cattle by diets low in carotenoids, so that marbling development is inversely correlated with serum vitamin A levels [39]. In rodents, the administration of RA (reviewed in [6]) or retinal [85] reduces body weight and body fat, and increases insulin sensitivity. Long-term vitamin A supplementation (as retinyl palmitate) has been shown to associate with a mild reduction of adiposity in rats [41] and has certain counterbalancing effect on the development of diet-induced obesity in mice [15]. On the other hand, feeding mice with a vitamin A deficient diet results in a marked increase in adiposity [58]. Of note, there are studies linking a low dietary intake of vitamin A with a high incidence of obesity in certain human populations [72, 78]. Even if, in rodents, increases in skeletal muscle fatty acid oxidation [1] and changes in liver metabolism (Amengual et al., unpublished results) can contribute to the RA slimming effect, there is strong evidence that the major role of carotenoid derivatives is on adipose tissue (see next section).

\section{Effect of $\beta$-carotene and its metabolites on adipose tissue biology}

Adipose tissue is primarily a lipid storage organ. To perform this function it is in active communication with other organs, receiving and sending signals [74]. Alterations in the secretion of these molecules, and also in the ability of adipose tissue to expand appropriately under conditions of positive energy balance, have been shown to influence the aetiology of several pathologies including type II diabetes and cardiovascular diseases. Interestingly, the adipose tissue, and adipocytes in particular, are also the main $\beta$-carotene storage sites in humans [37]. Therefore, it is particularly relevant to study the effect of $\beta$-carotene on this organ, especially in relation to adipocyte differentiation, adipokine secretion, and lipid metabolism, which are crucial aspects of adipose tissue biology. Since BCMO1 and $\mathrm{BCDO} 2$ are expressed in adipocytes [29], the possibility exists that the cleavage products could be found in adipocytes. In fact, retinal, which can be produced via BCMO1 cleavage, has been detected in adipose tissue [85]. RAs resulting from oxidation of retinal by RALDHs are also quantifiable in adipose tissue in vivo [52], especially all-trans RA; whereas evidence of the existence of 9-cis RA in vivo is still lacking $[35,52,68]$. Finally, apocarotenals resulting from asymmetric cleavage of $\beta$-carotene can be generated in vivo [31] and may influence parameters of adipose tissue biology, even if no data are currently available on the presence of these molecules in adipocytes.

\section{Adipocyte differentiation}

Adipose tissue is highly plastic. It has an enormous capacity to expand through hypertrophy and hyperplasia of adipocytes. Preadipocytes can differentiate to adipocytes. This differentiation is triggered by nutritional and hormonal signals that activate a cascade of transcription factors including the CCAAT/enhancer binding proteins (C/EBPs) and peroxisome proliferator-activated receptor $\gamma(\operatorname{PPAR} \gamma)$, the latter being considered as the master regulator of adipogenesis (for review see [14]).

The effect of $\beta$-carotene has been depicted on the differentiation of 3T3-L1 preadipocytes, the prototypical model for such studies [38]. Results showed that $\beta$-carotene strongly inhibited adipose conversion of 3T3-L1 cells. However, based on these results, one cannot exclude a vitamin $\mathrm{A}$ rather than a $\beta$-carotene effect. Indeed, it is well known that vitamin A derivatives are strong repressors of adipocyte differentiation. This was established long ago for RA [42], and a recent article elegantly demonstrated that physiological concentration of retinal represses adipogenesis in vitro and in vivo [85] through inhibition of RXR $\alpha$ (retinoid $\mathrm{X}$ receptor $\alpha$ ) and PPAR $\gamma$-activation by their respective ligands (Fig. 2). The same group has also shown that the asymmetric cleavage product $\beta$-apo-14'-carotenal (but not $\beta$-apo- $8^{\prime}$ carotenal and $\beta$-apo- $12^{\prime}$-carotenal) presents inhibitory properties on preadipocyte differentiation via suppression of $\operatorname{PPAR} \alpha, \operatorname{PPAR} \gamma$ and RXR-activation by their respective ligands [86].

RA has been largely studied as a modulator of mammalian gene expression. Main effects are mediated by two types of nuclear hormone receptors: the retinoid $\mathrm{X}$ receptors $(\operatorname{RXR} \alpha, \operatorname{RXR} \beta$ and $\operatorname{RXR} \gamma)$, which are responsive to 
9-cis RA and the retinoic acid receptors ( $\operatorname{RAR} \alpha, \operatorname{RAR} \beta$ and $\operatorname{RAR} \gamma$ ), responsive to all-trans and 9-cis RA. These nuclear receptors have very broad repercussions on general homeostasis. RXRs act as partners to other class II nuclear receptors, including thyroid hormone receptor, vitamin D receptor, PPAR, farnesoid $\mathrm{X}$ receptor and the liver $\mathrm{X}$ receptor, leading to multiple biological effects [22]. Similarly, RARs with RXRs as heterodimerisation partners have biological effects ranging from morphogenesis and organogenesis, to cell growth, differentiation and apoptosis [22].

In the specific context of adipocyte differentiation, the effect of all-trans RA has been related to several events (reviewed in [6]). Among them, RAs interfered with $\mathrm{C} / \mathrm{EBP}$ proteins, which resulted in a blockage of induction of downstream target genes, including PPAR $\gamma$. An effect on $\operatorname{RAR} \gamma$ (up-regulation) and $\operatorname{RXR} \alpha$ (down-regulation) expression has been demonstrated, which modifies the assembly of nuclear receptors heterodimers involved in adipogenesis. Finally, effects of RAs on the retinoblastoma protein may favour the proliferative ability, and thus reduce the differentiation ability of preadipocytes. Interestingly, low concentrations (1-10 nM) of RAs, contrary to high concentrations $(0.1-1 \mu \mathrm{M})$, appear to have a stimulating effect on adipogenesis (reviewed in [6]).

Finally, it should also be taken into account that both in vivo and in vitro RA (all-trans and 9-cis) has been shown to induce the expression of uncoupling protein-1 (UCP1), the molecular marker of brown adipocytes. Provitamin A carotenoids also induced UCP1 expression in primary brown adipocytes differentiated in culture [61]. This induction is explained by the existence of RA and PPAR response elements in the $U C P 1$ gene promoter. Induction of other UCP family members by all-trans RA has also been reported (see [6]).

\section{Adipokine production}

Adipokines are bioactive proteins secreted by the adipose tissue that act locally or at a distance to affect adipose tissue growth and whole body metabolism. More than 50 different adipokines have been identified so far, including: adiponectin, leptin, resistin, acylation stimulating protein, fasting-induced adipose factor, enzymes involved in lipoprotein metabolism and various cytokines, chemokines and acute phase proteins $[59,62,69,74]$. In 2005, vitamin A plasma transporter RBP4 (retinol binding protein-4) of adipose origin was identified as a new adipokine favouring insulin resistance in mice through effects on liver and muscle [79], which are more likely independent of vitamin A. Among carotenoid/retinoids, RAs appear as the more active on adipokine regulation. In particular, inhibitory effects of RA (all-trans and 9-cis) on the expression/ secretion of leptin [17, 32, 33], resistin [16], and RBP4 specifically of adipose origin [49] have been described, both in in vivo (in adipose tissue of treated animals) and adipocyte cell models. Resistin and adipose RBP4, as well as hyperleptinemia in the setting of leptin resistance, have been linked to insulin resistance so that the observed effects could be viewed as beneficial. It should be noted, however, that the insulin-sensitising hormone adiponectin has also been shown to be down-regulated in perirenal adipose tissue of mice after acute all-trans RA treatment [84]. $\beta$-apo-14'-carotenal also promoted a decrease of adiponectin expression during 3T3-L1 differentiation [86].

\section{Lipid metabolism}

Data on the lipidic metabolism of adipocytes treated with either $\beta$-carotene or apocarotenals are scarce. To the best of our knowledge, only studies dealing with all-trans RA have been published. These studies showed that both in in vivo (in treated mice) and mature 3T3-L1 adipocytes, all-trans RA triggered remodelling to reduce lipogenesis and increased oxidative metabolism, as shown by gene expression changes, histological changes and in the case of cultured cells, increases in lipolysis and fatty acid oxidation $[50,51]$.

\section{Prospective}

Biological properties of $\beta$-carotene most probably depend on the complex interplay between (among others factors) $\beta$-carotene dosage, physiological state of the organism and genetic make-up. Enzymes involved in $\beta$-carotene cleavage clearly play a significant role in its in vivo properties by regulating the nature of the metabolites. The function of $\mathrm{BCMO} 1$ as the key enzyme in the production of vitamin A from provitamin A seems well established, as observed in $\mathrm{BCMOI}^{-/-}$mice and identification of SNPs modulating $\beta$-carotene conversion efficiency and $\beta$-carotene status. Besides, studying the genetic variation in $\mathrm{BCDO} 2$ gene might help to gain information into its physiological function. Adipose tissue, being the main $\beta$-carotene storage site of the body and expressing both BCMO1 and BCDO2, appears a priori as an important site for $\beta$-carotene actions. Numerous studies have investigated the effect of the different cleavage products of $\beta$-carotene on adipose tissue biology. Indeed, it has been well described that retinoic acids strongly impact on adipocyte differentiation, adipokine secretion and lipid metabolism. Some results were also obtained with retinal or $\beta$-apo-14'-carotenal, but the effect of intact $\beta$-carotene remains largely unknown. To investigate the specific effects of intact $\beta$-carotene, the use of the $\mathrm{BCMOI}^{-1-}$ mice would be particularly relevant, since these 
animals are unable to cleave $\beta$-carotene, and therefore absorb and accumulate it in its native form in their tissues. Finally, the influence of genetic variations in carotenoid oxygenase genes on lipid disorders such as liver steatosis, insulin resistance and metabolic syndrome could be investigated to verify whether the observations in $\mathrm{BCMO1}^{-1-}$ mice also apply to the human situation (thereby confirming the role of BCMO1 in lipid metabolism). These data should provide new insights on the mechanisms of carotenoids in disease prevention.

Acknowledgment The authors acknowledge the European Nutrigenomics Network NuGO for funding the "Carotenoids" focus team. They are grateful to Drs Aldona Dembiska-Kiec (JUMC Krakow, Poland), Patrick Borel (INRA 1260 Marseille, France), Chris Evelo (BiGCat Maastricht, The Netherlands), Andreu Palou and Joan Ribot (UIB, Spain) for their comments about the manuscript

Conflict of interest statement The authors declare having no conflict-of-interest.

\section{References}

1. Amengual J, Ribot J, Bonet ML, Palou A (2008) Retinoic acid treatment increases lipid oxidation capacity in skeletal muscle of mice. Obesity (Silver Spring) 16(3):585-591

2. Amiot-Carlin MJ, Babot-Laurent C, Tourniaire F (2008) Plant pigments as bioactive substances. In: Socaciu C (ed) Food colorants: chemical and functional properties. CRC Press, Boca Raton, pp 127-146

3. Bachmann H, Desbarats A, Pattison P, Sedgewick M, Riss G, Wyss A, Cardinault N, Duszka C, Goralczyk R, Grolier P (2002) Feedback regulation of beta, beta-carotene $15,15^{\prime}$-monooxygenase by retinoic acid in rats and chickens. J Nutr 132(12):3616-3622

4. Barua AB, Olson JA (2000) beta-carotene is converted primarily to retinoids in rats in vivo. J Nutr 130(8):1996-2001

5. Bjelakovic G, Nikolova D, Gluud LL, Simonetti RG, Gluud C (2008) Antioxidant supplements for prevention of mortality in healthy participants and patients with various diseases. Cochrane Database Syst Rev (2):CD007176

6. Bonet ML, Ribot J, Felipe F, Palou A (2003) Vitamin A and the regulation of fat reserves. Cell Mol Life Sci 60(7):1311-1321

7. Borel P, Grolier P, Mekki N, Boirie Y, Rochette Y, Le Roy B, Alexandre-Gouabau MC, Lairon D, Azais-Braesco V (1998) Low and high responders to pharmacological doses of beta-carotene: proportion in the population, mechanisms involved and consequences on beta-carotene metabolism. J Lipid Res 39(11):22502260

8. Borel P, Moussa M, Reboul E, Lyan B, Defoort C, VincentBaudry S, Maillot M, Gastaldi M, Darmon M, Portugal H, Lairon D, Planells R (2009) Human fasting plasma concentrations of vitamin $\mathrm{E}$ and carotenoids, and their association with genetic variants in apo C-III, cholesteryl ester transfer protein, hepatic lipase, intestinal fatty acid binding protein and microsomal triacylglycerol transfer protein. Br J Nutr 101(5):680-687

9. Borel P, Moussa M, Reboul E, Lyan B, Defoort C, VincentBaudry S, Maillot M, Gastaldi M, Darmon M, Portugal H, Planells R, Lairon D (2007) Human plasma levels of vitamin E and carotenoids are associated with genetic polymorphisms in genes involved in lipid metabolism. J Nutr 137(12):2653-2659
10. Coyne T, Ibiebele TI, Baade PD, Dobson A, McClintock C, Dunn S, Leonard D, Shaw J (2005) Diabetes mellitus and serum carotenoids: findings of a population-based study in Queensland, Australia. Am J Clin Nutr 82(3):685-693

11. During A, Dawson HD, Harrison EH (2005) Carotenoid transport is decreased and expression of the lipid transporters SR-BI, NPC1L1, and ABCA1 is downregulated in Caco-2 cells treated with ezetimibe. J Nutr 135(10):2305-2312

12. Edwards AJ, You CS, Swanson JE, Parker RS (2001) A novel extrinsic reference method for assessing the vitamin A value of plant foods. Am J Clin Nutr 74(3):348-355

13. Elliott R (2005) Mechanisms of genomic and non-genomic actions of carotenoids. Biochim Biophys Acta 1740(2):147-154

14. Farmer SR (2006) Transcriptional control of adipocyte formation. Cell Metab 4(4):263-273

15. Felipe F, Bonet ML, Ribot J, Palou A (2003) Up-regulation of muscle uncoupling protein 3 gene expression in mice following high fat diet, dietary vitamin A supplementation and acute retinoic acid-treatment. Int J Obes Relat Metab Disord 27(1):60-69

16. Felipe F, Bonet ML, Ribot J, Palou A (2004) Modulation of resistin expression by retinoic acid and vitamin A status. Diabetes 53(4):882-889

17. Felipe F, Mercader J, Ribot J, Palou A, Bonet ML (2005) Effects of retinoic acid administration and dietary vitamin A supplementation on leptin expression in mice: lack of correlation with changes of adipose tissue mass and food intake. Biochim Biophys Acta 1740(2):258-265

18. Fierce Y, de Morais Vieira M, Piantedosi R, Wyss A, Blaner WS, Paik J (2008) In vitro and in vivo characterization of retinoid synthesis from beta-carotene. Arch Biochem Biophys 472(2):126-138

19. Ford ES, Mokdad AH, Giles WH, Brown DW (2003) The metabolic syndrome and antioxidant concentrations: findings from the Third National Health and Nutrition Examination Survey. Diabetes 52(9):2346-2352

20. Ford ES, Will JC, Bowman BA, Narayan KM (1999) Diabetes mellitus and serum carotenoids: findings from the Third National Health and Nutrition Examination Survey. Am J Epidemiol 149(2):168-176

21. Gallicchio L, Boyd K, Matanoski G, Tao XG, Chen L, Lam TK, Shiels M, Hammond E, Robinson KA, Caulfield LE, Herman JG, Guallar E, Alberg AJ (2008) Carotenoids and the risk of developing lung cancer: a systematic review. Am J Clin Nutr 88(2):372-383

22. Germain P, Chambon P, Eichele G, Evans RM, Lazar MA, Leid M, De Lera AR, Lotan R, Mangelsdorf DJ, Gronemeyer H (2006) International Union of Pharmacology. LXIII. Retinoid X receptors. Pharmacol Rev 58(4):760-772

23. Goldbohm RA, Brants HA, Hulshof KF, van den Brandt PA (1998) The contribution of various foods to intake of vitamin A and carotenoids in The Netherlands. Int $\mathrm{J}$ Vitam Nutr Res 68(6):378-383

24. Granado F, Olmedilla B, Blanco I, Rojas-Hidalgo E (1996) Major fruit and vegetable contributors to the main serum carotenoids in the Spanish diet. Eur J Clin Nutr 50(4):246-250

25. Harrison EH (2005) Mechanisms of digestion and absorption of dietary vitamin A. Annu Rev Nutr 25:87-103

26. Hebuterne X, Wang XD, Smith DE, Tang G, Russell RM (1996) In vivo biosynthesis of retinoic acid from beta-carotene involves and excentric cleavage pathway in ferret intestine. J Lipid Res 37(3):482-492

27. Heinonen M (1991) Food groups as the source of retinoids, carotenoids, and vitamin $\mathrm{A}$ in Finland. Int $\mathrm{J}$ Vitam Nutr Res 61(1):3-9

28. Herbeth B, Gueguen S, Leroy P, Siest G, Visvikis-Siest S (2007) The lipoprotein lipase serine 447 stop polymorphism is associated 
with altered serum carotenoid concentrations in the Stanislas Family Study. J Am Coll Nutr 26(6):655-662

29. Hessel S, Eichinger A, Isken A, Amengual J, Hunzelmann S, Hoeller U, Elste V, Hunziker W, Goralczyk R, Oberhauser V, von Lintig J, Wyss A (2007) CMO1 deficiency abolishes vitamin A production from beta-carotene and alters lipid metabolism in mice. J Biol Chem 282(46):33553-33561

30. Hickenbottom SJ, Follett JR, Lin Y, Dueker SR, Burri BJ, Neidlinger TR, Clifford AJ (2002) Variability in conversion of beta-carotene to vitamin $\mathrm{A}$ in men as measured by using a double-tracer study design. Am J Clin Nutr 75(5):900-907

31. Ho CC, de Moura FF, Kim SH, Clifford AJ (2007) Excentral cleavage of beta-carotene in vivo in a healthy man. Am J Clin Nutr 85(3):770-777

32. Hollung K, Rise CP, Drevon CA, Reseland JE (2004) Tissuespecific regulation of leptin expression and secretion by all-trans retinoic acid. J Cell Biochem 92(2):307-315

33. Hong SE, Ahn IS, Jung HS, Rayner DV, Do MS (2004) Effect of retinoic acid on leptin, glycerol, and glucose levels in mature rat adipocytes in vitro. J Med Food 7(3):320-326

34. Kahn SE, Hull RL, Utzschneider KM (2006) Mechanisms linking obesity to insulin resistance and type 2 diabetes. Nature 444(7121):840-846

35. Kane MA, Chen N, Sparks S, Napoli JL (2005) Quantification of endogenous retinoic acid in limited biological samples by LC/MS/MS. Biochem J 388(Pt 1):363

36. Kang HW, Bhimidi GR, Odom DP, Brun PJ, Fernandez ML, McGrane MM (2007) Altered lipid catabolism in the vitamin A deficient liver. Mol Cell Endocrinol 271(1-2):18-27

37. Kaplan LA, Lau JM, Stein EA (1990) Carotenoid composition, concentrations, and relationships in various human organs. Clin Physiol Biochem 8(1):1-10

38. Kawada T, Aoki N, Kamei Y, Maeshige K, Nishiu S, Sugimoto E (1990) Comparative investigation of vitamins and their analogues on terminal differentiation, from preadipocytes to adipocytes, of 3T3-L1 cells. Comp Biochem Physiol A Comp Physiol 96(2):323-326

39. Kawada T, Kamei Y, Sugimoto E (1996) The possibility of active form of vitamins A and D as suppressors on adipocyte development via ligand-dependent transcriptional regulators. Int J Obes Relat Metab Disord 20(Suppl 3):S52-S57

40. Krinsky NI, Johnson EJ (2005) Carotenoid actions and their relation to health and disease. Mol Aspects Med 26(6):459-516

41. Kumar MV, Sunvold GD, Scarpace PJ (1999) Dietary vitamin A supplementation in rats: suppression of leptin and induction of UCP1 mRNA. J Lipid Res 40(5):824

42. Kuri-Harcuch W (1982) Differentiation of 3T3-F442A cells into adipocytes is inhibited by retinoic acid. Differentiation 23(2):164-169

43. Lampert JM, Holzschuh J, Hessel S, Driever W, Vogt K, von Lintig J (2003) Provitamin A conversion to retinal via the beta, beta-carotene-15,15'-oxygenase (bcox) is essential for pattern formation and differentiation during zebrafish embryogenesis. Development 130(10):2173-2186

44. Leung WC, Hessel S, Meplan C, Flint J, Oberhauser V, Tourniaire F, Hesketh JE, von Lintig J, Lietz G (2009) Two common single nucleotide polymorphisms in the gene encoding beta-carotene $15,15^{\prime}$-monoxygenase alter beta-carotene metabolism in female volunteers. FASEB J 23:1041-1053. doi: 10.1096/ fj.08-121962

45. Sies H, Stahl W, Sundquist AR (1992) Antioxidant functions of vitamins. Vitamins $\mathrm{E}$ and $\mathrm{C}$, beta-carotene, and other carotenoids. Ann N Y Acad Sci 669:7-20

46. Lietz G, Mulokozi G, Henry JC, Tomkins AM (2006) Xanthophyll and hydrocarbon carotenoid patterns differ in plasma and breast milk of women supplemented with red palm oil during pregnancy and lactation. J Nutr 136(7):1821-1827

47. Lin Y, Dueker SR, Burri BJ, Neidlinger TR, Clifford AJ (2000) Variability of the conversion of beta-carotene to vitamin A in women measured by using a double-tracer study design. Am J Clin Nutr 71(6): 1545-1554

48. Lindqvist A, Sharvill J, Sharvill DE, Andersson S (2007) Loss-offunction mutation in carotenoid $15,15^{\prime}$-monooxygenase identified in a patient with hypercarotenemia and hypovitaminosis A. J Nutr 137(11):2346-2350

49. Mercader J, Granados N, Bonet ML, Palou A (2008) All-trans retinoic acid decreases murine adipose retinol binding protein 4 production. Cell Physiol Biochem 22(1-4):363-372

50. Mercader J, Madsen L, Felipe F, Palou A, Kristiansen K, Bonet ML (2007) All-trans retinoic acid increases oxidative metabolism in mature adipocytes. Cell Physiol Biochem 20(6):1061-1072

51. Mercader J, Ribot J, Murano I, Felipe F, Cinti S, Bonet ML, Palou A (2006) Remodeling of white adipose tissue after retinoic acid administration in mice. Endocrinology 147(11):5325-5332

52. Mic FA, Molotkov A, Benbrook DM, Duester G (2003) Retinoid activation of retinoic acid receptor but not retinoid $\mathrm{X}$ receptor is sufficient to rescue lethal defect in retinoic acid synthesis. Proc Natl Acad Sci USA 100(12):7135-7140

53. Moore T, Holmes PD (1971) The production of experimental vitamin A deficiency in rats and mice. Lab Anim 5(2):239-250

54. Paetau I, Khachik F, Brown ED, Beecher GR, Kramer TR, Chittams J, Clevidence BA (1998) Chronic ingestion of lycopene-rich tomato juice or lycopene supplements significantly increases plasma concentrations of lycopene and related tomato carotenoids in humans. Am J Clin Nutr 68(6):1187-1195

55. Ramakrishna V, Jailkhani R (2007) Evaluation of oxidative stress in insulin dependent diabetes mellitus (IDDM) patients. Diagn Pathol 2:22

56. Ramakrishna V, Jailkhani R (2008) Oxidative stress in non-insulin-dependent diabetes mellitus (NIDDM) patients. Acta Diabetol 45(1):41-46

57. Ribaya-Mercado JD, Solon FS, Solon MA, Cabal-Barza MA, Perfecto CS, Tang G, Solon JA, Fjeld CR, Russell RM (2000) Bioconversion of plant carotenoids to vitamin A in Filipino school-aged children varies inversely with vitamin A status. Am J Clin Nutr 72(2):455-465

58. Ribot J, Felipe F, Bonet ML, Palou A (2001) Changes of adiposity in response to vitamin A status correlate with changes of PPAR gamma 2 expression. Obes Res 9(8):500-509

59. Rosen ED, Spiegelman BM (2006) Adipocytes as regulators of energy balance and glucose homeostasis. Nature 444(7121):847853

60. Sauvant P, Mekki N, Charbonnier M, Portugal H, Lairon D, Borel $P$ (2003) Amounts and types of fatty acids in meals affect the pattern of retinoids secreted in human chylomicrons after a highdose preformed vitamin A intake. Metabolism 52(4):514-519

61. Serra F, Bonet ML, Puigserver P, Oliver J, Palou A (1999) Stimulation of uncoupling protein 1 expression in brown adipocytes by naturally occurring carotenoids. Int J Obes Relat Metab Disord 23(6):650-655

62. Sethi JK, Vidal-Puig AJ (2007) Thematic review series: adipocyte biology. Adipose tissue function and plasticity orchestrate nutritional adaptation. J Lipid Res 48(6):1253-1262

63. Shiota G (2005) Loss of function of retinoic acid in liver leads to steatohepatitis and liver tumor: a NASH animal model. Hepatol Res 33(2): 155-160

64. Strobel M, Tinz J, Biesalski HK (2007) The importance of betacarotene as a source of vitamin A with special regard to pregnant and breastfeeding women. Eur J Nutr 46(Suppl 1):I1-I20

65. Sugiura M, Nakamura M, Ogawa K, Ikoma Y, Matsumoto H, Ando F, Shimokata H, Yano M (2008) Associations of serum 
carotenoid concentrations with the metabolic syndrome: interaction with smoking. Br J Nutr 100(6):1297-1306

66. Takitani K, Zhu CL, Inoue A, Tamai H (2006) Molecular cloning of the rat beta-carotene $15,15^{\prime}$-monooxygenase gene and its regulation by retinoic acid. Eur J Nutr 45(6):320-326

67. Tang G, Qin J, Dolnikowski GG, Russell RM (2003) Shortterm (intestinal) and long-term (postintestinal) conversion of beta-carotene to retinol in adults as assessed by a stable-isotope reference method. Am J Clin Nutr 78(2):259-266

68. Tang GW, Russell RM (1990) 13-cis-retinoic acid is an endogenous compound in human serum. J Lipid Res 31(2):175-182

69. Trayhurn P, Wood IS (2004) Adipokines: inflammation and the pleiotropic role of white adipose tissue. Br J Nutr 92(3):347-355

70. Tyssandier V, Choubert G, Grolier P, Borel P (2002) Carotenoids, mostly the xanthophylls, exchange between plasma lipoproteins. Int J Vitam Nutr Res 72(5):300-308

71. van Bennekum A, Werder M, Thuahnai ST, Han CH, Duong P, Williams DL, Wettstein P, Schulthess G, Phillips MC, Hauser H (2005) Class B scavenger receptor-mediated intestinal absorption of dietary beta-carotene and cholesterol. Biochemistry 44(11): $4517-4525$

72. Vaughan LA, Benyshek DC, Martin JF (1997) Food acquisition habits, nutrient intakes, and anthropometric data of Havasupai adults. J Am Diet Assoc 97(11):1275-1282

73. von Lintig J, Hessel S, Isken A, Kiefer C, Lampert JM, Voolstra O, Vogt K (2005) Towards a better understanding of carotenoid metabolism in animals. Biochim Biophys Acta 1740(2):122-131

74. Wang P, Mariman E, Renes J, Keijer J (2008) The secretory function of adipocytes in the physiology of white adipose tissue. J Cell Physiol 216(1):3-13

75. Wang XD (1994) Review: absorption and metabolism of betacarotene. J Am Coll Nutr 13(4):314-325

76. Wang XD, Krinsky NI, Tang GW, Russell RM (1992) Retinoic acid can be produced from excentric cleavage of beta-carotene in human intestinal mucosa. Arch Biochem Biophys 293(2):298-304

77. Wang Z, Yin S, Zhao X, Russell RM, Tang G (2004) Betacarotene-vitamin A equivalence in Chinese adults assessed by an isotope dilution technique. Br J Nutr 91(1):121-131
78. Wolfe WS, Sanjur D (1988) Contemporary diet and body weight of Navajo women receiving food assistance: an ethnographic and nutritional investigation. J Am Diet Assoc 88(7):822-827

79. Yang Q, Graham TE, Mody N, Preitner F, Peroni OD, Zabolotny JM, Kotani K, Quadro L, Kahn BB (2005) Serum retinol binding protein 4 contributes to insulin resistance in obesity and type 2 diabetes. Nature 436(7049):356-362

80. Yeum KJ, dos Anjos Ferreira AL, Smith D, Krinsky NI, Russell RM (2000) The effect of alpha-tocopherol on the oxidative cleavage of beta-carotene. Free Radic Biol Med 29(2):105-114

81. Yeum KJ, Lee-Kim YC, Yoon S, Lee KY, Park IS, Lee KS, Kim BS, Tang G, Russell RM, Krinsky NI (1995) Similar metabolites formed from beta-carotene by human gastric mucosal homogenates, lipoxygenase, or linoleic acid hydroperoxide. Arch Biochem Biophys 321(1):167-174

82. Ylonen K, Alfthan G, Groop L, Saloranta C, Aro A, Virtanen SM (2003) Dietary intakes and plasma concentrations of carotenoids and tocopherols in relation to glucose metabolism in subjects at high risk of type 2 diabetes: the Botnia Dietary Study. Am J Clin Nutr 77(6):1434-1441

83. Yonekura L, Nagao A (2007) Intestinal absorption of dietary carotenoids. Mol Nutr Food Res 51(1):107-115

84. Zhang Y, Matheny M, Zolotukhin S, Tumer N, Scarpace PJ (2002) Regulation of adiponectin and leptin gene expression in white and brown adipose tissues: influence of beta3-adrenergic agonists, retinoic acid, leptin and fasting. Biochim Biophys Acta 1584(2-3):115-122

85. Ziouzenkova O, Orasanu G, Sharlach M, Akiyama TE, Berger JP, Viereck J, Hamilton JA, Tang G, Dolnikowski GG, Vogel S, Duester G, Plutzky J (2007) Retinaldehyde represses adipogenesis and diet-induced obesity. Nat Med 13(6):695-702

86. Ziouzenkova O, Orasanu G, Sukhova G, Lau E, Berger JP, Tang G, Krinsky NI, Dolnikowski GG, Plutzky J (2007) Asymmetric cleavage of beta-carotene yields a transcriptional repressor of retinoid $\mathrm{X}$ receptor and peroxisome proliferatoractivated receptor responses. Mol Endocrinol 21(1):77-88 